OPEN ACCESS

Edited by:

Gretta Pecl,

Centre for Marine Socioecology,

Australia

Reviewed by:

Judy Lawrence,

Victoria University of Wellington,

New Zealand

Ioannis Souliotis,

Imperial College London,

United Kingdom

*Correspondence:

Théophile Bongarts Lebbe tbongarts@ocean-climate.org Agathe Euzen

Agathe.EUZEN@cnrs-dir.fr

Specialty section:

This article was submitted to

Ocean Solutions,

a section of the journal

Frontiers in Marine Science

Received: 13 July 2021

Accepted: 14 October 2021

Published: 03 November 2021

Citation:

Bongarts Lebbe T, Rey-Valette $H$, Chaumillon É, Camus G, Almar R, Cazenave A, Claudet J, Rocle N, Meur-Férec $C$, Viard F, Mercier $D$,

Dupuy C, Ménard F, Rossel BA,

Mullineaux $L$, Sicre M-A, Zivian $A$, Gaill $F$ and Euzen A (2021) Designing

Coastal Adaptation Strategies

to Tackle Sea Level Rise.

Front. Mar. Sci. 8:740602.

doi: 10.3389/fmars.2021.740602

\section{Designing Coastal Adaptation Strategies to Tackle Sea Level Rise}

Théophile Bongarts Lebbe ${ }^{1 *}$, Hélène Rey-Valette ${ }^{2}$, Éric Chaumillon ${ }^{3}$, Guigone Camus ${ }^{4}$, Rafael Almar ${ }^{5}$, Anny Cazenave ${ }^{6}$, Joachim Claudet $^{7}$, Nicolas Rocle ${ }^{8,9}$, Catherine Meur-Férec ${ }^{10}$, Frédérique Viard ${ }^{11}$, Denis Mercier ${ }^{12}$, Christine Dupuy ${ }^{3}$, Frédéric Ménard ${ }^{13}$, Bernardo Aliaga Rossel ${ }^{14}$, Lauren Mullineaux ${ }^{15}$, Marie-Alexandrine Sicre ${ }^{16}$, Anna Zivian ${ }^{17}$, Françoise Gaill ${ }^{18}$ and Agathe Euzen ${ }^{19 *}$

${ }^{1}$ Ocean \& Climate Platform, Paris, France, ${ }^{2}$ CEE-M, CNRS, INRAE, Institut Agra, Université de Montpellier, Montpellier, France, ${ }^{3}$ LIENSS, CNRS, La Rochelle University, La Rochelle, France, ${ }^{4}$ Laboratoire des Sciences du Climat et de l'Environnement, LSCE/IPSL, CEA-CNRS-UVSQ Paris-Saclay University, Saclay, France, ${ }^{5}$ LEGOS, IRD, Toulouse University, Toulouse, France, ${ }^{6}$ LEGOS, CNRS, Toulouse University, Toulouse, France, ${ }^{7}$ National Center for Scientific Research, CNRS, PSL Université Paris, CRIOBE, Paris, France, ${ }^{8}$ Institut National de Recherche pour l'Agriculture, l'Alimentation et l'Environnement, Paris, France, ${ }^{9}$ Secretariat of the Pacific Regional Environment Programme, Apia, Samoa, ${ }^{10}$ LETG, UBO, CNRS, Brest, France, ${ }^{11}$ ISEM, Univ Montpellier, CNRS, IRD, Montpellier, France, ${ }^{12}$ Laboratory of Physical Geography, Sorbonne University, Paris, France, ${ }^{13}$ MIO, CNRS, IRD, Aix Marseille University, Toulon University, Marseille, France, ${ }^{14}$ Intergovernmental Oceanographic Commission of UNESCO, Paris, France, ${ }^{15}$ Biology Department, Woods Hole Oceanographic Institution, Woods Hole, MA, United States, ${ }^{16}$ LOCEAN, Campus Pierre et Marie Curie, CNRS, Sorbonne University, Paris, France, ${ }^{17}$ Ocean Conservancy, Santa Cruz, CA, United States, ${ }^{18}$ Ocean \& Climate Platform, Paris, France, ${ }^{19}$ INEE, CNRS, Paris, France

Faced with sea level rise and the intensification of extreme events, human populations living on the coasts are developing responses to address local situations. A synthesis of the literature on responses to coastal adaptation allows us to highlight different adaptation strategies. Here, we analyze these strategies according to the complexity of their implementation, both institutionally and technically. First, we distinguish two opposing paradigms - fighting against rising sea levels or adapting to new climatic conditions; and second, we observe the level of integrated management of the strategies. This typology allows a distinction between four archetypes with the most commonly associated governance modalities for each. We then underline the need for hybrid approaches and adaptation trajectories over time to take into account local sociocultural, geographical, and climatic conditions as well as to integrate stakeholders in the design and implementation of responses. We show that dynamic and participatory policies can foster collective learning processes and enable the evolution of social values and behaviors. Finally, adaptation policies rely on knowledge and participatory engagement, multi-scalar governance, policy monitoring, and territorial solidarity. These conditions are especially relevant for densely populated areas that will be confronted with sea level rise, thus for coastal cities in particular.

Keywords: climate change, sea level rise, adaptation, governance, nature-based solutions, multidisciplinary approach, vulnerability, coastal cities

\section{INTRODUCTION}

Addressing sea level rise (SLR) resulting from climate change is one of the greatest societal challenges of this century. According to the IPCC Special Report on Ocean and Cryosphere in a Changing Climate (2019), Global Mean Sea Level (GMSL) rose by $17 \mathrm{~cm}$ over the 20th century and this phenomenon is accelerating (Dangendorf et al., 2019; IPCC, 2019). Thus, by 2050, one billion 
people living in low-lying areas will be exposed to coastal hazards (Merkens et al., 2016). SLR entails a set of risks for coastal areas, especially for coastal megacities, tropical regions, and small islands. These risks include permanent and/or short periods of submersion, disruption of coastal ecosystem functioning and destruction of these ecosystems, soil and aquifer salinization, and modification of natural drainage systems (IPCC, 2019). By 2100 extreme SLR events will become frequent, regardless of the selected emission scenario (IPCC, 2019) and more regions are projected to become exposed to coastal flooding and inundation (Almar et al., 2021).

Based on information and recommendations from IPCC reports as well as on locally led research, elected representatives and coastal risk managers exert their organizational efforts at different scales to better define effective adaptation strategies. But while global SLR projections are essential, they are not sufficient to support decisions for local adaptation. Indeed, sea level does not rise uniformly. Furthermore, the smaller the scale, the more sea level and exposure to coastal hazards depend on other factors than climate (IPCC, 2019). On a local scale, three factors need to be taken into account: regional GMSL variations ( $\pm 30 \%$ IPCC, 2019), small-scale coastal processes (such as shelf currents, small-scale eddies, density changes due to freshwater input in river deltas; Durand et al., 2019; Woodworth et al., 2019), and relative sea level that depends on natural and anthropogenic coastal movements of land subsidence or uplift (Herrera-García et al., 2021). In addition to the intricacy of modeling small-scale processes (Castelle and Chaumillon, 2019), elected representatives and coastal risk managers are responsible for implementing case-by-case climate action plans, which include different parameters such as vulnerability to SLR (Le Bars et al., 2020) and a wide range of sociocultural and economic factors. Their decisions also depend on the trade-offs among responses based on a protection approach and responses based on an integrated approach, including managed retreat. Ideally, decision-makers commit to co-construction of responses with the exposed populations.

We propose scientific and pragmatic elements that can accompany and support local adaptation choices. Our collective and multidisciplinary approach (from climate science to social sciences, including anthropology, sociology, ecology, geosciences, geography, law, oceanography, and economics) holds that the co-construction of knowledge and practices is a crucial prerequisite in the face of the challenges presented by SLR. Elected officials and coastal risk managers are keen for support and advice in designing, improving, and implementing their management and policy responses in a context of high uncertainty (Toimil et al., 2021) and social change.

We first establish a reference typology of governance archetypes for responding to SLR based on IPCC reports, scientific guidelines, and published literature. Integrating contexts and conditions of local governance, the typology shows the diversity of responses implemented. In addition, based on the presentation of in situ experiences and more recent research, the article proposes a new model of coastal responses that engage stakeholders, facilitate social uptake, and consider broader societal goals. In the second part, we argue the value of hybrid approaches that integrate social solidarity at the regional level, a less common theme in the specialized literature. In Part "Governance of Hybrid Responses," we focus on the dynamic dimensions of response planning and implementations. Dynamic responses are dependent on institutional and governance adaptation and even transformation. Adaptive and dynamic responses further require hybridization, flexibility (Holling, 2005), and innovation (Haasnoot et al., 2021). These are essential to the planning of long-term dynamic pathways and to designing the new model of coastal adaptation presented here. Finally, the discussion raises the challenges and research perspectives that coastal managers and stakeholders now have to consider. This study, with its analysis and contextualization of coastal adaptation responses, can support decision-making when developing local action plans.

\section{TYPOLOGIES OF ADAPTATION RESPONSES TO SEA LEVEL RISE}

Various responses can enable densely populated coastal areas to adapt to SLR, erosion, and coastal flooding. Based on different guidelines and reviews published to date (Linham and Nicholls, 2010; IPCC, 2014, 2019; Hill, 2015; Bambridge and et Latouche, 2016; Haasnoot et al., 2021), we note a general agreement on the distinctions among three main categories of response: protection (including advance), accommodation, and managed retreat. These categories differ in their vision more than in their implementation. However, authors use different terminology, which raises questions about how adaptation responses are grouped. For example, in Linham and Nicholls (2010), coastal wetland restoration, which takes nature into account, is classified as an accommodation response because it raises awareness and helps reverse maladaptive trends. In contrast, the IPCC (2019) considers all ecosystem-based adaptation (EbA) responses as protection responses, as they serve to fight against rising sea levels. Some responses fit in more than one category: EbA responses can accompany managed retreat, as coastal ecosystems can be reestablished following the destruction of dikes or depoldering. Similarly, a protection response initially designed to stabilize the coastline can be used during a transitional period before implementing managed retreat. Depending on the authors, EbA and Nature-based Solutions (NbS) can have the same meaning. In our analysis, we consider $\mathrm{NbS}$ as ways to protect or restore ecosystem services. Thus, we have considered them EbA responses.

Here, our intention is to analyze the different adaptation responses considering the complexity of implementing them; that is, to what extent they consider whole system responses, including both natural systems and socio-cultural and economic systems. Then, we propose a synthesis of four governance archetypes to address coastal hazards considering two contrasting paradigms and taking into account the level of integration of responses.

\section{Hard Protection}

Hard protection, or "gray infrastructure" responses, are widespread and especially concentrated in northwestern Europe, 
East Asia, and in deltas or densely populated areas such as coastal cities (IPCC, 2019). Although there is no technological limit that constrains a seawall's maximum height, hard protective structures do not provide a reliable, long-term response to coastal hazards (Ballinger, 2002), as seawalls can exacerbate erosion, affect the seabed and neighboring coasts, and diminish the ability of the coastline to respond naturally to changing conditions (van Rijn, 2011). Hard protection includes dikes and static seawalls that are effective in stabilizing the shoreline but cause scour and can destabilize the beach; groins and artificial headlands that intercept long-shore sand transport and are effective in building the beach updrift but induce scour and erosion downdrift; detached breakwaters and artificial reefs that reduce wave activity and energy along the shoreline and are effective in building beaches but can produce downdrift erosion (Gracia et al., 2018).

A new response emerged in the IPCC (2019) typology: the advance response. Advance response refers to the creation of artificial land above the sea and has a long history in densely populated areas as a way to create new buildable areas. Its main advantage is the high accessibility of new sites, both by sea and by land, which is an asset for ports as well as residential and recreational development (Alves et al., 2020). Coastal cities can develop their waterfront or benefit from infrastructure with direct access to the ocean by building offshore, protecting themselves from the sea behind seawalls and dikes (Donchyts et al., 2016).

Both hard and advance responses can alter overall coastal ecosystem functioning, degrade the quality of ecosystem services, and lead to habitat loss or reduced species diversity (Bilkovic and Mitchell, 2013; Sutton-Grier et al., 2015; Warner et al., 2018). These responses contribute to 'ocean sprawl' (Bishop et al., 2017) with large-scale ecological impacts on local and surrounding ecosystems, for instance by influencing connectivity patterns (i.e., the movement of organisms), displacing species due to the environmental changes they cause, facilitating the establishment of non-native invasive species, and/or displacing existing human uses or housing (Anguelovski et al., 2016). Finally, despite their effectiveness, these responses also remain very costly or even completely unaffordable (Hinkel et al., 2018), and while the technology exists to build enormously high sea walls, economic constraints and social acceptability will preclude their viability (Esteban et al., 2019).

The Netherlands is most emblematic in terms of implementation of hard responses, due to the country's long experience developing gray infrastructure. However, in recent years, projected climate-driven SLR, along with the development of a stakeholder-led, integrative vision of the future coast have led some governing bodies to reconsider the Dutch national strategy, favoring adapting to rather than fighting change. The concept of 'climate proofing' was born in the Netherlands with the goal of making the most populated cities and ports resilient to climate change. The city of Rotterdam has the goal of being the "safest port city in the world" by 2025, and the Dutch government has prioritized sustainable development of coastal areas as its strategy for the 21st century by choosing to better integrate natural systems when designing responses to SLR (Kabat et al., 2009).

\section{Soft Protection}

Also originally rooted in the Netherlands (Kabat et al., 2009), the second strategy covers soft protection responses that still fight against marine intrusion - that is, SLR and coastal flooding - but by applying an integrated approach rather than hard protection. Awareness of the negative impacts of hard protection on erosion and sedimentation patterns (van Rijn, 2011), as well as on ecosystems and the services they provide (de Schipper et al., 2020), led to a growing recognition of the benefits of soft protection.

Dune rehabilitation and sand nourishment, including beach nourishment, allow the coast to respond dynamically to change (van Rijn, 2011). van Slobbe et al. (2013) present these responses as part of a "building with Nature" strategy that provides an effective response to protect beaches and coastal areas. For Hinkel et al. (2013), optimal beach and shore nourishment responses offer economic and social benefits and can reduce forced migration, although soft adaptation is a temporary response to SLR.

Soft adaptation is mostly focused on beach nourishment, considered as an environmentally friendly protection response for coastal ecosystems (Linham and Nicholls, 2010). A number of national reviews present examples of sites threatened by SLR where beach nourishment has been implemented. For instance, in the U.S., the volume of sand used for this purpose has increased exponentially over the last century, particularly in California (Elko et al., 2021). Pinto et al. (2020) provide an overview of beach nourishment practices since the 1950s in Portugal, while Pagán et al. (2020) analyze the evolution of beaches and beach areas over the same period and show the extent to which anthropogenic actions have affected the coastline. Karaliūnas et al. (2020) assess how the different conditions for beach nourishment transform the coastal landscape in Lithuania. Somphong et al. (2020) provide general estimates on the cost and volume of sand needed to supply all Thailand's beaches. In China, Liu et al. (2020) present the practices, the reasons for deploying beach nourishment, and the technological advances made in recent decades.

However, the literature points to negative physical and biological changes it can cause in beach ecosystem services (Fegley et al., 2020), as well as other ecological and socioeconomic impacts (de Schipper et al., 2020). An open question for the development of beach nourishment is the accessibility of beach-compatible sand. Not all coastlines have large sand reserves. The largest sand nourishment experiment in the world was conducted on the Dutch coast, which has ample reserves (Stive et al., 2013). de Schipper et al. (2020) have shown that beach nourishment can have socio-economic impacts, particularly on recreational activities. Thus, the increased interest in the development of adaptable, sustainable, and effective soft engineering other coastal responses than beach nourishment to preserve sandy coastlines is noteworthy.

\section{Accommodation to Reduce Vulnerability}

A third category of response is accommodation, which takes projected SLR into account when adapting existing infrastructure to changing climatic conditions. Accommodation responses, also 
called "coastal planning techniques" by Alves et al. (2020), are not homogeneous but rather encompass diverse methods with a common goal: mitigating coastal hazards. Rather than building infrastructure, accommodation responses comprise a variety of technological, architectural, and urban planning responses. Linham and Nicholls (2010) include technologies and innovations that physically modify exposed buildings or infrastructure by raising buildings, protecting them individually, adapting urban drainage systems, or developing floating housing (Thi Thu Trang, 2016) and exploring "New Urbanism" (Smith et al., 2021). Lauterjung and Letz (2017) also include information systems, flood hazard mapping, contingency plans, and insurance schemes that improve understanding and awareness of coastal risks among residents and elected officials and enable the development of appropriate responses.

These accommodation responses may also involve strengthening monitoring capacity, establishing new rules and policies, producing and disseminating useful information, and promoting safer behavior (Linham and Nicholls, 2010). Most accommodation responses tend to be resource intensive in terms of monitoring systems, studies, communication, development of new strategies for coastal protection, and management.

Recently, a literature review from West Africa (Alves et al., 2020) discussed accommodation, noting that the continent's accommodation responses are still insufficiently developed, with the exception of early warning systems in the cities of Cotonou, Benin; Dakar, Senegal; Accra, Ghana; and Lagos, Nigeria. In many countries where accommodation responses exist, the review highlights that the systems fail due to a lack of maintenance.

\section{Ecosystem-Based Adaptation}

$\mathrm{EbA}$ - which includes the restoration of salt marshes, mangroves, oyster beds, or coral reefs (Powell et al., 2019) - consists in letting coastal ecosystems mitigate marine flooding and coastal erosion (Cheong et al., 2013; Temmerman et al., 2013) and reduce risks for people living in coastal areas (Barbier et al., 2011; Zhang et al., 2012).

Substantial work has been done on the efficiency of mangroves (McIvor et al., 2013; Möller et al., 2014), salt marshes (Guannel et al., 2016; Leonardi et al., 2018), oyster beds (Morris et al., 2019), and coral reefs (Ferrario et al., 2014; Roelvink et al., 2021) that shows how and under what conditions these ecosystems can attenuate wave power, reduce erosion, and more generally enhance coastal protection. However, the IPCC (2019) shows that accelerated SLR and climate change may lead to significant coastal ecosystem loss by the end of the century. Moreover, Gao et al. (2020) published a review on coastal dune migration, trends, and dominant drivers of dune mobility and concludes that human intervention played a dominant role in altering it. More globally, coastal ecosystems are threatened if they are caught between the sea and the built environment, lacking the natural conditions enabling them to move.

Implementing $\mathrm{EbA}$ requires a deep understanding of the ecology of the species involved (Salvador de Paiva et al., 2018), and David (2020) raises the risk of introducing new invasive species, thus questioning its use as an EbA. For instance, examination of the fundamental and realized niche of oysters has shown that oyster beds respond differently to a wide range of biotic and abiotic factors, varying across locations, which calls for further investigation to improve the services these ecosystems provide (Morris et al., 2019). Oyster restoration can introduce invasive species, especially under changing climatic conditions. Rinde et al. (2017) study a Pacific oyster species that has been proposed for coastal protection in several countries, including the U.S. and Netherlands, and highlight the potential of increased invasiveness because of climate-change effects and the concomitant risk to native species and habitats in temperate regions.

Mangrove restoration has the added value of providing cobenefits such as carbon sequestration and habitat provision (e.g., Sierra-Correa and Cantera Kintz, 2015). Beyond adaptation to SLR, coastal marshes, seagrass, and mangroves are referred to as "blue carbon" due to their contribution to long-term carbon storage (Mcleod et al., 2011). Salt marshes, mangroves, oyster reefs, and coral reefs also provide multiple ecological functions, such as nursing grounds for fish and shellfish, resting places for migratory birds, and groundwater and surface water runoff filtration. Increasingly, scientists and international institutions emphasize the use of EbA to connect adaptation to SLR to biodiversity conservation. For example, Alves et al. (2020) show that diverse coastal ecosystem rehabilitation projects, including mangrove restoration projects that cover large coastal areas, provide multiple benefits for coastal species as well as climate mitigation and adaptation.

\section{Managed Retreat}

While SLR will reshape coastal ecosystems and population distribution (see, for the U.S., Hauer, 2017; and globally, see IPCC, 2019) managed retreat involves rethinking living on the coast by accepting that certain coastal infrastructure, neighborhoods, or even cities will need to relocate entirely. This response can take place at different scales and levels of complexity - resettling a few particularly exposed houses, relocating entire neighborhoods, moving large cities, or moving entire island populations to new host countries. The larger the geographic scale at which managed retreat is implemented, the more anticipatory planning and cooperation are needed. Furthermore, if this response appears to be the most effective way to protect people and assets from coastal risks (Haasnoot et al., 2021), Barnett and O'Neill (2012) have shown that its implementation is complex and often highly controversial, both politically and socially. Managed retreat raises indeed a range of social, cultural, psychological, and economic considerations (Abel et al., 2011). Consequently, retreat has generally been carried out after extreme events, without planning ahead; Hino et al. (2017) report 27 cases of post-event, unmanaged relocation worldwide. However, there are currently communities planning for managed retreat strategies and working at defining pathways to get there (Lawrence et al., 2020).

Managed retreat is approached and deployed differently around the world. Apart from a few emblematic examples such as Jakarta, where the Indonesian government decided to relocate part of the city of Borneo (van de Vuurst and Escobar, 2020), or the ongoing relocation of the densely populated fishermen's 
district of Guet'Ndar in Saint-Louis, Senegal (World Bank, 2018), managed retreat responses with public support have primarily been carried out in developed countries (North America and Western and Northern Europe).

In the U.S., managed retreat is constrained by psychological, institutional, and practical limits (Siders, 2019). In Europe, although managing flooding risk through depoldering conveys ecosystem benefits, many countries still favor the reinforcement of dikes (Goeldner-Gianella et al., 2015). People are deeply attached to local polders and their uses, which explains optimism and status quo biases, and hinders thinking about managed retreat. Elected officials coastal managers can also be reluctant to implement managed retreat. Bragg et al. (2021) underline that the use of the term "managed retreat" can create anxiety amongst those least able to move, lead to resistance from those affected and to the abandonment of the policy. They note that the use of appropriate terminology and communication strategies remains crucial to increase acceptance of managed retreat.

French attempts and polices experiments are notable for their anticipatory and learning approach of managed retreat. As part of a national integrated coastline management strategy, pilot projects were implemented to identify legal, economic and operational constraints and psychological or political opposition. Rocle and Salles (2018) and Rocle et al. (2021) show that the pilot programs led by French government together with local institutions were successful in delivering innovative and actionable knowledge and tools (depending on scale and density of coastal development) through multi-level exchanges and multijurisdictional governance. Such an integrated approach leads to a better understanding of erosion management and coastal land use planning (Robert and Schleyer-Lindenmann, 2021), while emphasizing the need for observations and information or warnings for future owners. For instance, in order to prevent current economic losses, regulations can allow temporary construction in exposed areas for periods spanning over 30 years. Innovative planning concepts include buy-out programs to avoid future loss of value (André et al., 2016), and other scientific work explores innovations in compensation arrangements to reduce the expense of compensation (André et al., 2016; Henderson, 2018), although this can't be the only sufficient source of funding for relocation strategies.

\section{Governance Archetypes for Responding to Sea Level Rise}

Based on this typology of responses, we propose four governance archetypes for responding to SLR that allow us to rank the degree of complexity of implementing the different approaches to coastal adaptation.

In the synthesis table (Figure 1), archetypes are classified according to two contrasting paradigms positioned on the vertical axis. The first paradigm is to Protect from coastal hazards. It consists of fighting against advance of the sea in order to protect threatened population and infrastructure. By accepting coastline mobility, the second paradigm is to Adapt to coastal hazards. Through this paradigm, if certain areas must be ceded to the sea, it recommends planning ahead for the relocation of communities and activities to safe spaces. Regarding governance modalities, we postulate that the Level of stakeholder engagement in the decisionmaking process is low for responses that fit into the first paradigm, and high for responses that fit into the second paradigm.

The synthesis table also refers on the horizontal axis to how adaptation responses are planned and implemented, depending on whether they favor an Infrastructure-based approach, that is, technological or technical solutions, or an Integrated approach that considers broader societal goals. In terms of governance, we postulate that the more a response to coastal hazards is integrated, the bigger Spatial implementation scale needs to be.

Designing a new coastal model archetype promotes adaptation to new climatic conditions by adopting an integrated, systems-based approach. Thus, overcoming the complexity of implementing responses that correspond to this archetype requires a high level of stakeholder engagement in the decision-making process, as well as planning on a large spatial scale.

Because it is difficult to account for the diversity of governance arrangements, which are highly dependent on national political organization and capacities, the elements of governance represented do not always correspond to specific cases. Finally, a single response can fall into different governance archetypes. Indeed, responses are often connected and can be executed together (see "Governance of Hybrid Responses") in differing time frames (see "Toward Dynamic Coastal Management").

\section{GOVERNANCE OF HYBRID RESPONSES}

Responding to several technical, social, and ecological constraints, there is no one-size-fits-all solution for SLR. Here, we focus on strategies that consist in adapting to SLR through an integrated approach. Planning and implementation processes and constraints depend on social, geographical, ecosystem, and institutional contexts. We therefore emphasize the need to adopt hybrid responses and processes (see "Designing hybrid approaches to meet context-specific challenges"). We identify social, economic, and environmental issues that require attention but that may also facilitate individual and community responses and improve governance (see "Planning spatial hybridization of responses to foster territorial solidarity").

\section{Designing Hybrid Approaches to Meet Context-Specific Challenges}

Hybrid responses are increasingly numerous and diverse, providing coastal cities and territories with new effective opportunities to adapt to SLR by mixing strategies (Hill, 2015; Sutton-Grier et al., 2015). The IPCC (2019) acknowledges that hybrid responses are often a combination of protection, retreat, accommodation, advance, and $\mathrm{EbA}$ responses.

Sutton-Grier et al. (2015) define hybrid approaches as the combination of natural and built infrastructure to protect coastlines from erosion and flooding, aiming to be more costeffective in the long term than built infrastructure alone. They mention examples of hybrid approaches developed in the U.S. 


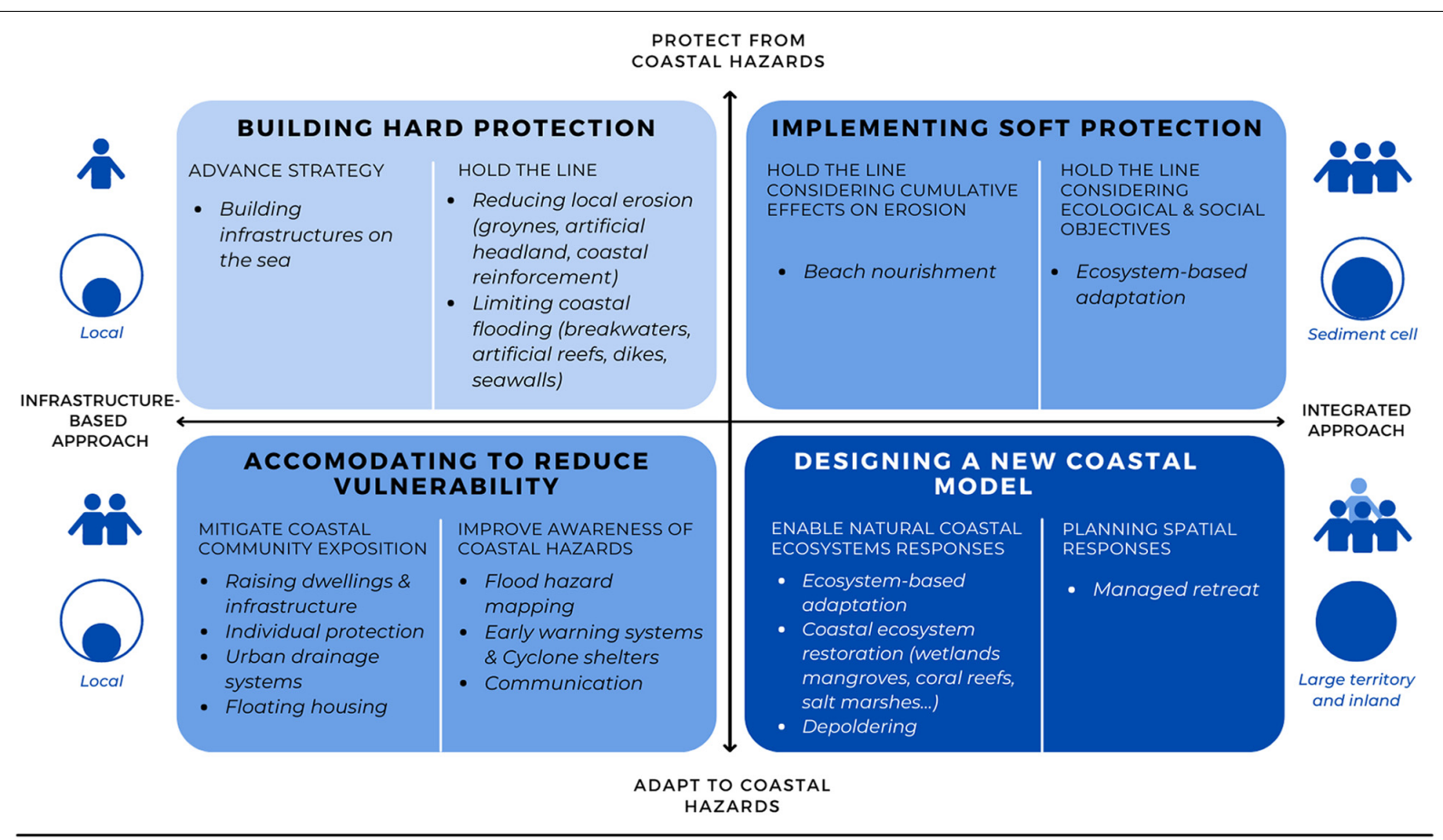

LEGEND - Governance modalities Level of stakeholder
engagement in decision-
making process
Spatial implementation scale

Local: one or a few coastal municipalities.

Sediment cell: several coastal municipalities at the sediment cell scale. Large territory and inland: several coastal and adjacent inland municipalities.

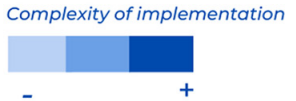

FIGURE 1 | Governance archetypes of adaptation strategies to sea level rise.

after Hurricane Sandy that combine many natural options (salt marsh restoration, rock groins, and oyster restoration) with infrastructure-based approaches, such as removable floodwalls or mobile floodgates that are only used when a storm is approaching. Seeking to capitalize on the best features of both built and natural infrastructures, hybrid approaches can provide a greater level of confidence than just EbA. They can also provide co-benefits, including enhancing social, economic, and ecological resilience of coasts and coastal communities, maintaining coastal ecosystem services, and preventing the loss of human life and property (Sutton-Grier et al., 2015).

While cost-benefit analyses generally result in a preference for hard responses over managed retreat and EbA- assuming high initial costs for future benefits (André et al., 2016) - limited evidence exists on the economic value of hybrid approaches (Sutton-Grier et al., 2015) more recent data demonstrates hybrid systems' effectiveness and provision of ecosystem services (Bilkovic and Mitchell, 2013). Du et al. (2020) conducted an economic assessment of hard, soft, and natural strategies, as well as hybrid strategies that combine the three, to face major floods in Shanghai and concluded that hybrid approaches can serve as a robust flood adaptation strategy.

However, while no single response can satisfy the diversity of local issues related to adaptation to SLR, the implementation of hybrid approaches may pose more governance challenges than hard protection responses do (Sutton-Grier et al.,
2015). The section below considers these governance responses and challenges.

\section{Planning Spatial Hybridization of Responses to Foster Territorial Solidarity}

IPCC experts (2019) underline that the implementation of coastal SLR adaptation responses poses a profound governance challenge due to difficult social and political choices. Here, governance challenges refer to institutional and organizational factors hindering the effective, efficient, and equitable implementation of responses (as defined in IPCC, 2019).

Meur-Ferec and Guillou (2020) highlight a governance constraint based on risk perceptions that can underestimate the effects of climate change. Drawing on Beck's (1997) 'risk society', Michelot (2015) defined the concept of 'risk culture' as a set of perceptions and behaviors adopted by a society in the face of risk to show that developing a new risk culture could be a solution to these constraints. For instance, the Building hard responses strategy can comfort and reassure people. But these behaviors can also be counterproductive and alter the risk perception, inducing a fear of disasters that can lead to subsequent difficulties dealing with danger. Focusing on disaster risk reduction measures, Martinez et al. (2020) identify a "culture of risk memory" as one of the prerequisites for successful collaboration and policy implementation. Public awareness of 
risk can be improved by building on local observation systems and scientific knowledge systems, involving local communities in planning, and promoting social learning about risks and potential local responses (Baird et al., 2014; Martinez et al., 2020; Bragg et al., 2021). Communication (Bragg et al., 2021) and, even more, involving stakeholders and the public are particularly important (Hügel and Davies, 2020).

More generally, a combination of decision analysis, coastal land use planning, civil society participation, scenario development, and conflict resolution can help address the complexity of implementing responses. For instance, Scyphers et al. (2020) recommend investigating potential pathways to navigate social, economic, and environmental influences on landowner decisions for coastal habitat conservation. Their study reveals opportunities for incentivizing living shorelines as a tool for coastal habitat conservation.

Finance, insurance, and management capacity are key governance issues for implementing hybrid responses. Airoldi et al. (2021) identify economic incentives that can be used to support sustainable development and reduce coastal risks. They discuss the rise of new financing avenues for natural infrastructure for flood risk reduction and climate adaptation, including green bonds and impact investments, blue bonds, incentives and funding for pre-disaster mitigation, post-disaster recovery funds, and insurance instruments.

The appropriate governance scale has been addressed through the notion of sediment cell, based on the scale of the physical phenomenon of sediment transport (Cooper and Pontee, 2006), considering that human interventions in each jurisdiction will affect neighboring jurisdictions; for example, sediment reduction from dams will impact the sediment cell they are part of, and deep-water ports will block sediment drift downstream (Almar et al., 2015; Guerrera et al., 2021). This issue has prompted several communities to cooperate in order to avoid the transfer of impact caused by gray infrastructure. It has also led communities to share certain costs, including for research or jointly paying for barge displacement for recharging operations. Thus, hybrid approaches involve financing arrangements that go beyond the communities or countries directly affected and broaden dialogue.

When addressing coastal risks through land use planning, often only small groups of affected citizens become involved, rather than the wider affected community that may also contribute to the funding of coastal adaptation (Clément et al., 2015; Anguelovski et al., 2016). For instance, inland communities, which also use beaches and protected coastal ecosystems, should be concerned by financing coastal adaptation. In addition, they may be affected by migrants retreating from coastal areas. Depending on the case, it is necessary to consider the appropriate fiscal scale to raise public funding or to access national and international funding sources. Yet for both developing and developed countries, inland populations are generally not consulted, nor are part-time residents and tourists (Rey-Valette et al., 2015). More generally, improving the coordination of responses at all levels of governance and across all sectors and policy domains, which has proven to be an effective response (IPCC, 2019), remains a major challenge.
Finally and importantly, coastal adaptation raises equity concerns, and requires ensuring that responses do not further marginalize the most vulnerable populations, especially in fastgrowing cities in developing countries (See and Wilmsen, 2020) and also in areas with large existing wealth and resource gaps, and do not trigger or aggravate social conflicts (McGinlay et al., 2021). Efforts to promote climate resilience should be undertaken alongside sustainable, just, and equitable development. Otherwise SLR is likely to cause or exacerbate social conflicts over time to the point of their becoming even more difficult to resolve; this is why we highlight the importance of considering larger scales and neighboring jurisdictions. We now focus on the key importance of considering multiple temporal scales.

\section{TOWARD DYNAMIC COASTAL MANAGEMENT}

The evolution of the world's coastlines presents uncertainties for the future (Le Cozannet et al., 2019; Le Bars et al., 2020), limiting our ability to anticipate risks and develop sustainable strategies. We emphasize the importance of planning dynamic coastal management to implement responses to SLR over time and to manage adaptively for uncertainty. By testing different pathways against different scenarios, the following approaches enables to identify signals and decision triggers for taking anticipatory action and articulate temporal scales to move toward desirable futures.

Reactive adaptation could be defined as "one shock, one reaction," whereas preventive adaptation is more about "building better for the future" (Nicholls, 2011). Reactive adaptation is notoriously costly and only moderately efficient (Nicholls, 2011). On the other hand, adaptive coastal management also entails certain constraints, notably regarding information on the evolution of physical processes and biases in the perception of future risks (Coquet et al., 2019). However, distant timeframes (2050 or, even more, 2100) make it very difficult to anticipate societal evolution (social and institutional) despite forwardlooking approaches. It will be necessary to be able to adapt under large uncertainty and over time frames beyond 2050, thus calling into question planning and decision-making practices as they are conceived today (Haasnoot et al., 2013; Bloemen et al., 2019; Kool et al., 2020; Rocle et al., 2020; Werners et al., 2021).

Pathway analysis is a low-cost tool to define long-term adaptation responses that Haasnoot et al. (2021) present as a positive approach to reduce coastal risks and minimize ineffective investments and social inequities. It enables adaptation to SLR over time and allows for alternative pathways. Some studies have presented different approaches to pathway development in different decision-making contexts (Bloemen et al., 2018; Bosomworth and Gaillard, 2019; Lawrence et al., 2019). For example, Haasnoot et al. (2019) investigated how uncertainty related to Antarctic melting could impact the coastal adaptation strategy of the Netherlands. These authors and Le Bars et al. (2020) identified key variables and processes for the adaptation of different coastal areas with a long-term vision to assist decisionmaking under high uncertainty. They propose a dynamic 
approach that leads to the identification of several trajectories based on previously identified tipping points.

This approach aims at defining the solution space to accelerate climate change adaptation, defined by Haasnoot et al. (2020) as the space within which opportunities and constraints determine why, how, when, and who adapts to climate risks. The solution space is shaped in an integrative approach, taking into account biophysical, cultural, socio-economic, and political-institutional dimensions at a given moment in time. In a recent article, Haasnoot et al. (2021) show that the space for available solutions is shrinking and that managed retreat is emerging as the main remaining response.

Based on this methodology and building upon archetypes of French coastal territories, Rocle et al. (2020) highlight several key social and institutional variables and processes leading to different adaptation pathways, which themselves depend on local contexts and how different stakeholders respond to climatic and socioeconomic parameters. Pathways planning implies holistic approaches and a new generation of coastline models as proposed by Bamunawala et al. (2020) and Ranasinghe (2020). If participatory, pathways planning enables engagement and governance, thus reinforcing the acceptance and implementation of responses by affected communities.

\section{DISCUSSION}

Policy makers' and coastal risk managers' understanding of coastal adaptation has evolved over the last two decades, as have the approaches, policy processes, and the responses developed in order to address coastal hazards. Analyzing the various adaptation responses mentioned in IPCC reports and in other scientific literature led us to define four governance archetypes for responding to SLR. Each offers feasible and actionable adaptation approaches. We note that adaptation is itself an adaptive process that responds to new climate conditions. Adaptation strategies need to consider an integrated approach that encompasses broader societal goals.

In the case of densely populated areas exposed to SLR, this consists in designing new coastal models that take into account local issues and address the complex governance context for implementation. To do so, coastal adaptation must be planned on large scales with broad stakeholder involvement regarding responses to SLR. This will allow the new coastal model to facilitate the effectiveness and acceptability of the selected adaptation responses. Finally, two frameworks for action are suggested: encourage hybrid responses to better take into account local contexts specificities and reinforcing territorial solidarity; and plan for long-term, dynamic pathways.

These frameworks need to encompass different types of interaction among the cities' or territories' stakeholders. This in turn requires new forms of actionable and institutionalized knowledge. This goes along with expanding the research fields and disciplines involved and improving monitoring. Actionable knowledge and data are needed at different scales that are targeted to coastal risk managers, which also implies the evolution of how decision-makers and researchers interact (Kopp et al.,
2019; Lawrence et al., 2021). Rocle et al. (2021) emphasize the value of actionable knowledge (Cash et al., 2003; Kirchhoff et al., 2013) for managed retreat through a framework that takes into consideration the credibility, legitimacy, salience, and applicability of knowledge. Their analysis of managed retreat governance in France shows the importance of organizational learning processes through multi-level construction of actionable knowledge, policy guidelines and practical tools.

There are still relatively few concrete examples of sustainable and effective solutions implemented on the ground to adapt to SLR. Despite the crucial role of coastal cities' adaptation to SLR included in both SDGs 9 and 11, a recent systematic review of the literature on adaptation policies (Berrang-Ford et al., 2021) highlights the lack of attention to this topic. Indeed, only $6 \%$ of the publications reviewed focus on cities and only $4 \%$ focus on the ocean and coastal areas. The same publication underlines the weakness of actions and monitoring tools for transformational adaptation, especially for risk reduction (Magnan et al., 2020). The authors reveal the preponderance of individual adaptations which are most often uncoordinated and small-scale - and they recognize that the scope and the speed of implementation are inversely related

We have two other further observations. First, the low mobilization of scientific knowledge and second, the need for multi-scalar knowledge (in terms of both time and space) that would help defining dynamic and adaptive schedules for action, which in turn imply specific monitoring needs. Magnan et al. (2020) concur in their Adaptation Gap Report 2020 United Nations Environment Programme. They highlight that "Actionable policies refer to the extent to which multi- and bilateral cooperation and national policies provide clear guidance on how to operationalize adaptation on the ground (i.e., beyond only providing strategic guidance)" (p. 29).

We suggest several key considerations related to knowledge, participation, societal parameters of adaptation, and monitoring of policies, in order to reinforce actionability, hybridization of responses, and long-term dynamic pathways.

(i) Hybridization refers not just to the contextualization of responses but also to the reinforcement of scientific knowledge-sharing. It is linked to a greater disciplinary openness and to a transformation of knowledge production processes through in partnership with stakeholders and civil society, who must be fully integrated in the collective learning entailed by adaptation policies. Knowledge should not be limited to scientific engineering and natural science, but must include local knowledge, contributing to greater awareness and collective learning (Iorns Magallanes and Watts, 2019; Werners et al., 2021). Different tools to gain an effective, collective commitment of citizens at all scales include a diversity of media, such as virtual reality or serious games (den Haan and van der Voort, 2018; Blackett et al., 2019). In this regard, the New Zealand case study analyzed by Lawrence et al. (2021) highlights both the information constraints of citizens and the need for a deep change in the knowledge production process. They emphasize the contribution of warning systems and 
different types of serious games, but also more generally the importance of institutional adaptations to facilitate the uptake of these tools. Because the consideration of local issues depends on communities' participation, collective learning could facilitate the understanding of risk, help develop capacity for action (Lawrence and Haasnoot, 2017), and allow for adoption of adaptation responses (Reed, 2008; Baird et al., 2014). It is thus important to go beyond the notion of awareness-raising to strengthen the medium-term commitment of stakeholders by mobilizing their knowledge and perceptions. Although scientific mediation initiatives tend to develop, the reality of coastline management is that this interaction is usually mediated by a single type of actor - engineering offices, which are then in charge of scientific knowledge transfer. Thus, despite their efforts to develop forward-looking and participatory approaches, natural and social scientists, as well as the public, often remain on the fringes of these initiatives.

(ii) At the institutional level, it is crucial to coordinate and articulate the geographic scales covered by multi-level governance (Abel et al., 2011; Piggott-McKellar et al., 2019; Schneider et al., 2020; McGinlay et al., 2021; Robert and Schleyer-Lindenmann, 2021). We have shown the relevance of comparing shared experiences and the positive role of multi-level governance (Rocle and Salles, 2018; Rocle et al., 2021). Efficacy and implementability depends on the policy construction process and on the institutional context. Coordination of initiatives and financial experiments usually occurs at the national level, with on-the-ground implementation at the local level (Shi, 2019; Berrang-Ford et al., 2021). Ensuring the continuity of strategies and implementation requires sustained funding and ongoing governance agreements. For several countries, these conditions depend internally on political stability and externally on the programmatic priorities of international donors. Our analysis shows the role of proactive governance capacities of institutions, which partly explains the difficulties in implementing adaptive strategies for several countries. This is particularly true in colonialized countries that recently became independent, where the legacy of extraction of wealth and a system of post-colonial Western administrative and legal tools dominate local and customary ways of conceiving adaptation (Bambridge and et Latouche, 2016). The struggle between endogenous and exogenous strategies often opens breaches and weakens political decisions for coastal adaptation.

(iii) The implementation of collaborative approaches leads to the diversification of questions. This requires a transdisciplinary approach with a focus on social impact and a connection with the needs and concerns of affected communities. As an example, Magnan et al. (2021) raised gender as an insufficiently addressed parameter. More generally, adaptation to climate change can have a negative impact on some social groups and localities by increasing poverty, vulnerability, and inequity. Coastal adaptation studies thus need to consider territorial inequalities from an environmental and social justice perspective (King et al., 2014; Clément et al., 2015; Anguelovski et al., 2016). Climate migration is also incompletely explored (Gioli et al., 2016; Hauer, 2017; Hino et al., 2017), because it usually focuses more on the resistance of migrating populations to leave their homes or neighborhoods, while the issue of new inhabitants' acceptance by inland populations is little addressed. And as shown by the modeling of population flows carried out for Florida by Treuer et al. (2018), out-migration can produce negative effects on tax revenues when homeowners decide to move out of the region. Migration also involves very large scales, especially for island countries.

(iv) From the perspective of sustainable adaptation, effective implementation of transformative actions, such as new coastal models (see Figure 1), involves a gradual implementation. Longevity of responses requires adaptive approaches over time with improved monitoring (Bloemen et al., 2018; Bosomworth and Gaillard, 2019; Carstens et al., 2019; Haasnoot et al., 2019). Lawrence et al. (2021) suggest a logical chain of action (monitor, review, update, anticipate) that focuses on the role of information and continuity of follow-up. Since the elaboration of adaptive approaches over time depends on countries' institutional characteristics (Bloemen et al., 2018; Bosomworth and Gaillard, 2019; Carstens et al., 2019; Haasnoot et al., 2019), many policy practices and information and monitoring systems are not standardized or static (Magnan et al., 2020, 2021; Berrang-Ford et al., 2021). Local and multidisciplinary coastal data are far from being widely available (Le Bars et al., 2020; Rocle et al., 2020), so there is also a need for new generation of multi-scale, probabilistic coastal change models to adapt in conditions of great uncertainty (Ranasinghe, 2020).

In line with the studies on adaptation to climate change generally, our findings for coastal adaptation advocate for improving anticipation proposing trajectories based on different greenhouse gas emission scenarios (Berrang-Ford et al., 2021). This implies more regular monitoring processes to facilitate the anticipation and management of adaptation and to identify in real time the subtle signals of changing trends. It is necessary to reinforce the temporal frequency and the geographical resolution of data through multi-source observation systems or big data mining processes. Moreover, the improvement of information and monitoring systems would offer a better evaluation of the effects of different adaptation responses. This is especially true in terms of damage costs and vulnerability reduction for ecosystems, economies, and communities (Berrang-Ford et al., 2021). Then, to implement and facilitate the governance of adaptation policies, making a better use of multidisciplinary knowledge will be a key to success. These conditions are necessary for the deployment of effective actions, involving and raising the awareness of all stakeholders, from coastal managers to citizens, for an adaptation that is equal to the great challenges of the future. 


\section{AUTHOR CONTRIBUTIONS}

TBL and HR-V wrote the first draft, supported by an expanded editorial committee with $\mathrm{FG}$ and $\mathrm{AE}$, and with input from ÉC, GC, RA, AC, JC, NR, CM-F, FV, DM, CD, and AZ. All authors edited and contributed critical feedback. TBL, HR-V, GC, NR, JC, and $\mathrm{AZ}$ worked on revisions. All authors are accountable for the content of the manuscript.

\section{FUNDING}

This work was conducted as part of the project SEATIES led by the Ocean \& Climate Platform. SEA'TIES is funded

\section{REFERENCES}

Abel, N., Gorddard, R., Harman, B., Leitch, A., Langridge, J., Ryan, A., et al. (2011). Sea level rise, coastal development and planned retreat: Analytical framework, governance principles and an Australian case study. Environ. Sci. Policy 14, 279-288. doi: 10.1016/j.envsci.2010.12.002

Airoldi, L., Beck, M. W., Firth, L. B., Bugnot, A. B., Steinberg, P. D., and Dafforn, K. A. (2021). Emerging solutions to return nature to the urban ocean. Annu. Rev. Mar. Sci. 13, 445-477. doi: 10.1146/annurev-marine-032020-0 20015

Almar, R., Kestenare, E., Reyns, J., Jouanno, J., Anthony, E. J., Laibi, R., et al. (2015). Response of the Bight of Benin (Gulf of Guinea, West Africa) coastline to anthropogenic and natural forcing, Part1: Wave climate variability and impacts on the longshore sediment transport. Continent. Shelf Res. 110, 48-59. doi: 10.1016/j.csr.2015.09.020

Almar, R., Ranasinghe, R., Bergsma, E. W. J., Diaz, H., Melet, A., Papa, F., et al. (2021). A global analysis of extreme coastal water levels with implications for potential coastal overtopping. Nat. Commun. 12:3775. doi: 10.1038/s41467021-24008-9

Alves, B., Angnuureng, D. B., Morand, P., and Almar, R. (2020). A review on coastal erosion and flooding risks and best management practices in West Africa: What has been done and should be done. J. Coastal Conserv. 24:38. doi: 10.1007/s11852-020-00755-7

André, C., Boulet, D., Rey-Valette, H., and Rulleau, B. (2016). Protection by hard defence structures or relocation of assets exposed to coastal risks: Contributions and drawbacks of cost-benefit analysis for long-term adaptation choices to climate change. Ocean Coastal Manage. 134, 173-182. doi: 10.1016/j. ocecoaman.2016.10.003

Anguelovski, I., Shi, L., Chu, E., Gallagher, D., Goh, K., Lamb, Z., et al. (2016). Equity impacts of urban land use planning for climate adaptation: critical perspectives from the global North and South. J. Plan. Educ. Res. 36, 333-348. doi: $10.1177 / 0739456$ X16645166

Baills, A., Garcin, M., and Bulteau, T. (2020). Assessment of selected climate change adaptation measures for coastal areas. Ocean Coast. Manag. 185:105059. doi: 10.1016/j.ocecoaman.2019.105059

Baird, J., Plummer, R., Haug, C., and Huitema, D. (2014). Learning effects of interactive decision-making processes for climate change adaptation. Glob. Environ. Change 27, 51-63. doi: 10.1016/j.gloenvcha.2014.04.019

Ballinger, R. C. (2002). Coastal defences: processes, problems and solutions. Peter W. French, xvii +366 pp., $24 \times 16 \times 2$ cm, ISBN 0415198445 hardback, GB $£ 90.00$, London, UK/New York, USA: Routledge, 2001. Environ. Conserv. 29, 540-546. doi: 10.1017/S0376892902270393

Bambridge, T., and et Latouche, J.-P. (ed.) (2016). Les Atolls du Pacifique Face au Changement Climatique : Une Comparaison Tuamotu - Kiribati. Paris: Karthala, 121-173.

Bamunawala, J., Dastgheib, A., Ranasinghe, R., van der Spek, A., Maskey, S., Murray, A. B., et al. (2020). A holistic modeling approach to project the evolution of inlet-interrupted coastlines over the 21st Century. Front. Mar. Sci. 7:542. doi: 10.3389/fmars.2020.00542 by the Prince Albert II Foundation (No. 3112), Veolia Foundation (No. 20EB2004), and Fondation de France, Monaco. It was coordinated by the CNRS, in the framework of the RTPi (International Multidisciplinary Thematic Network) which drives the scientific component of the SEA'TIES project.

\section{ACKNOWLEDGMENTS}

We thank Brice Anselme, Gérard Blanchard, Lisa Devignol, Nathalie Hervé-Fournereau, Anne Kapuscinski, Denis Lacroix, Gonéri Le Cozannet, Nathalie Long, Chloé Orland, Sarah Palazot, David Salas, and Tiffany Wise-West for earlier discussions and helpful feedback on this manuscript.

Barbier, E. B., Hacker, S. D., Kennedy, C., Koch, E. W., Stier, A. C., and Silliman, B. R. (2011). The value of estuarine and coastal ecosystem services. Ecol. Monogr. 81, 169-193. doi: 10.1890/10-1510.1

Barnett, J., and O'Neill, S. (2012). Islands, resettlement and adaptation. Nat. Climate Change 2, 8-10.

Beck, U. (1997). The reinvention of politics: rethinking modernity in the global social Order Cambridge: Polity Press. Am. J. Sociol. 103, 1734-1735. doi: 10. $1086 / 231416$

Berrang-Ford, L., Siders, A. R., Lesnikowski, A. C., Fischer, A. P., Callaghan, M., Haddaway, N. R., et al. (2021). A systematic global stocktake of evidence on human adaptation to climate change Analysis. Durham, NC: Research Square.

Bilkovic, D. M., and Mitchell, M. M. (2013). Ecological tradeoffs of stabilized salt marshes as a shoreline protection strategy: Effects of artificial structures on macrobenthic assemblages. Ecol. Engin. 61, 469-481. doi: 10.1016/j.ecoleng. 2013.10.011

Bishop, M. J., Mayer-Pinto, M., Airoldi, L., Firth, L. B., Morris, R. L., Loke, L. H. L., et al. (2017). Effects of ocean sprawl on ecological connectivity: Impacts and solutions. J. Exper. Mar. Biol. Ecol. 492, 7-30. doi: 10.1016/j.jembe.2017 .01 .021

Blackett, P., Davies, K., Davies, B., Holland, P., and Cradock-Henry, N. (2019). Adaptive Futures: an Interactive Serious Game for Decision-Making and Coastal Hazards. Prepared for Natural Hazards Research Platform. NIWA Client Report No. 2019328HN. New Zealand: NIWA.

Bloemen, P., Reeder, T., Zevenbergen, C., Rijke, J., and Kingsborough, A. (2018). Lessons learned from applying adaptation pathways in flood risk management and challenges for the further development of this approach. Mitigat. Adapt. Strat. Glob. Change 23, 1083-1108. doi: 10.1007/s11027-0179773-9

Bloemen, P., Van Der Steen, M., and Van Der Wal, Z. (2019). Designing a century ahead: Climate change adaptation in the Dutch Delta. Policy Soc. 38, 58-76. doi: 10.1080/14494035.2018.1513731

Bosomworth, K., and Gaillard, E. (2019). Engaging with uncertainty and ambiguity through participatory 'Adaptive Pathways' approaches: Scoping the literature. Environ. Res. Lett. 14:093007. doi: 10.1088/1748-9326/ab3095

Bragg, W. K., Gonzalez, S. T., Rabearisoa, A., and Stoltz, A. D. (2021). Communicating managed retreat in California. Water 13:781. doi: 10.3390/ w13060781

Carstens, C., Sonnek, K. M., Räty, R., Wikman-Svahn, P., Carlsson-Kanyama, A., and Metzger, J. (2019). Insights from testing a modified dynamic adaptive policy pathways approach for spatial planning at the municipal level. Sustainability 11:433. doi: 10.3390/su11020433

Cash, D., Clark, W. C., Alcock, F., Dickson, N., Eckley, N., and Jager, J. (2003). Salience, credibility, legitimacy and boundaries: linking research, assessment and decision making. SSRN Elec. J. 24. doi: 10.2139/ssrn.3 72280

Castelle, B., and Chaumillon, E. (2019). Coastal change in tropical overseas and temperate metropolitan france inferred from a national monitoring network: A summary from the current special issue. J. Coast. Res. 88:3. doi: 10.2112/SI88002.1 
Cheong, S.-M., Silliman, B., Wong, P. P., van Wesenbeeck, B., Kim, C.-K., and Guannel, G. (2013). Coastal adaptation with ecological engineering. Nat. Climate Change 3, 787-791. doi: 10.1038/nclimate1854

Clément, V., Rey-Valette, H., and Rulleau, B. (2015). Perceptions on equity and responsibility in coastal zone policies. Ecol. Econ. 119, 284-291.

Cooper, N. J., and Pontee, N. I. (2006). Appraisal and evolution of the littoral 'sediment cell' concept in applied coastal management: Experiences from England and Wales. Ocean Coast. Manage. 49, 498-510. doi: 10.1016/j. ocecoaman.2006.04.003

Coquet, M., Mercier, D., and Fleury-Bahi, G. (2019). Assessment of the exposure to coastal flood risk by inhabitants of French coasts: The effect of spatial optimism and temporal pessimism. Ocean Coast. Manage. 177, 139-147. doi: 10.1016/j. ocecoaman.2019.05.004

Dangendorf, S., Hay, C., Calafat, F. M., Marcos, M., Piecuch, C. G., Berk, K., et al. (2019). Persistent acceleration in global sea-level rise since the 1960s. Nat. Climate Change 9, 705-710. doi: 10.1038/s41558-019-0531-8

David, A. A. (2020). Oyster reef restoration and biological invasions: An Overlooked or a Non-issue? Front. Mar. Sci. 7:544691. doi: 10.3389/fmars.2020. 544691

de Schipper, M. A., Ludka, B. C., Raubenheimer, B., Luijendijk, A. P., and Schlacher, T. A. (2020). Beach nourishment has complex implications for the future of sandy shores. Nat. Rev. Earth Environ. 2, 70-84. doi: 10.1038/s43017-02000109-9

den Haan, R.-J., and van der Voort, M. (2018). On evaluating social learning outcomes of serious games to collaboratively address sustainability problems: A literature review. Sustainability 10:4529. doi: 10.3390/su10124529

Donchyts, G., Baart, F., Winsemius, H., Gorelick, N., Kwadijk, J., and van de Giesen, N. (2016). Earth's surface water change over the past 30 years. Nat. Climate Change 6, 810-813. doi: 10.1038/nclimate3111

Du, S., Scussolini, P., Ward, P. J., Zhang, M., Wen, J., Wang, L., et al. (2020). Hard or soft flood adaptation? Advantages of a hybrid strategy for Shanghai. Glob. Environ. Change 61:102037. doi: 10.1016/j.gloenvcha.2020.102037

Durand, F., Piecuch, C. G., Becker, M., Papa, F., Raju, S. V., Khan, J. U., et al. (2019). Impact of continental freshwater runoff on coastal sea level. Surveys Geophys. 40, 1437-1466. doi: 10.1007/s10712-019-09536-w

Elko, N., Briggs, T. R., Benedet, L., Robertson, Q., Thomson, G., Webb, B. M., et al. (2021). A century of U.S. beach nourishment. Ocean Coast. Manage. 199:105406. doi: 10.1016/j.ocecoaman.2020.105406

Esteban, M., Jamero, M. L., Nurse, L., Yamamoto, L., Takagi, H., Thao, N. D., et al. (2019). Adaptation to sea level rise on low coral islands: Lessons from recent events. Ocean Coast. Manage. 168, 35-40. doi: 10.1016/j.ocecoaman.2018.10. 031

Fegley, S. R., Smith, J. P. S., Johnson, D., Schirmer, A., Jones-Boggs, J., Edmonds, A., et al. (2020). Nourished, exposed beaches exhibit altered sediment structure and meiofaunal communities. Diversity 12:245. doi: 10.3390/d12060245

Ferrario, F., Beck, M. W., Storlazzi, C. D., Micheli, F., Shepard, C. C., and Airoldi, L. (2014). The effectiveness of coral reefs for coastal hazard risk reduction and adaptation. Nat. Commun. 5:3794. doi: 10.1038/ncomms4794

Gao, J., Kennedy, D. M., and Konlechner, T. M. (2020). Coastal dune mobility over the past century: A global review. Prog. Physi. Geogr. Earth Environ. 44, 814-836. doi: 10.1177/0309133320919612

Gioli, G., Hugo, G., Costa, M. M., and Scheffran, J. (2016). Human mobility, climate adaptation, and development. Migrat. Dev. 5, 165-170. doi: 10.1080/21632324. 2015.1096590

Goeldner-Gianella, L., Bertrand, F., Oiry, A., and Grancher, D. (2015). Depolderisation policy against coastal flooding and social acceptability on the French Atlantic coast: The case of the Arcachon Bay. Ocean Coast. Manage. 116, 98-107. doi: 10.1016/j.ocecoaman.2015.07.001

Gracia, A., Rangel-Buitrago, N., Oakley, J. A., and Williams, A. T. (2018). Use of ecosystems in coastal erosion management. Ocean Coast. Manage. 156, 277-289. doi: 10.1016/j.ocecoaman.2017.07.009

Guerrera, F., Martín-Martín, M., Tramontana, M., Nimon, B., and Essotina Kpémoua, K. (2021). Shoreline changes and coastal erosion: The case study of the coast of togo (Bight of Benin, West Africa Margin). Geosciences 11:40. doi: 10.3390/geosciences11020040

Guannel, G., Arkema, K., Ruggiero, P., and Verutes, G. (2016). The power of three: coral reefs, seagrasses and mangroves protect coastal regions and increase their resilience. PLoS One 11:e0158094. doi: 10.1371/journal.pone.0158094
Haasnoot, M., Biesbroek, R., Lawrence, J., Muccione, V., Lempert, R., and Glavovic, B. (2020). Defining the solution space to accelerate climate change adaptation. Regional Environ. Change 20:37. doi: 10.1007/s10113-020-0 1623-8

Haasnoot, M., Brown, S., Scussolini, P., Jimenez, J. A., Vafeidis, A. T., and Nicholls, R. J. (2019). Generic adaptation pathways for coastal archetypes under uncertain sea-level rise. Environ. Res. Commun. 1:071006. doi: 10.1088/2515$7620 / \mathrm{ab} 1871$

Haasnoot, M., Kwakkel, J. H., Walker, W. E., and ter Maat, J. (2013). Dynamic adaptive policy pathways: A method for crafting robust decisions for a deeply uncertain world. Glob. Environ. Change 23, 485-498. doi: 10.1016/j.gloenvcha. 2012.12.006

Haasnoot, M., Lawrence, J., and Magnan, A. K. (2021). Pathways to coastal retreat. Science 372:1287. doi: 10.1126/science.abi6594

Hauer, M. E. (2017). Migration induced by sea-level rise could reshape the US population landscape. Nat. Climate Change 7, 321-325. doi: 10.1038/ nclimate 3271

Henderson, T. R. (2018). Sink or sell: using estate purchase options to facilitate coastal retreat. 71. Vanderbilt Law Review 71, 641-680.

Herrera-García, G., Ezquerro, P., Tomás, R., Béjar-Pizarro, M., López-Vinielles, J., Rossi, M., et al. (2021). Mapping the global threat of land subsidence. Science 371, 34-36. doi: 10.1126/science.abb8549

Hill, K. (2015). Coastal infrastructure: A typology for the next century of adaptation to sea-level rise. Front. Ecol. Environ. 13, 468-476. doi: 10.1890/150088

Hinkel, J., Aerts, J. C. J. H., Brown, S., Jiménez, J. A., Lincke, D., Nicholls, R. J., et al. (2018). The ability of societies to adapt to twenty-first-century sea-level rise. Nat. Climate Change 8, 570-578. doi: 10.1038/s41558-018-0176-z

Hinkel, J., Nicholls, R. J., Tol, R. S. J., Wang, Z. B., Hamilton, J. M., Boot, G., et al. (2013). A global analysis of erosion of sandy beaches and sea-level rise: An application of DIVA. Glob. Planet. Change 111, 150-158. doi: 10.1016/j. gloplacha.2013.09.002

Hino, M., Field, C. B., and Mach, K. J. (2017). Managed retreat as a response to natural hazard risk. Nat. Climate Change 7, 364-370. doi: 10.1038/nclimate3252

Holling, C. S. (2005). Adaptive environmental assessment and management, 1978 Edn. New Jersey: Blackburn Press.

Hügel, S., and Davies, A. R. (2020). Public participation, engagement, and climate change adaptation: A review of the research literature. WIREs Climate Change 11:e645. doi: 10.1002/wcc.645

Iorns Magallanes, C. J., and Watts, J. (2019). Adaptation to Sea-Level Rise: Local Government Liability Issues. Wellington: Deep South National Science Challenge, 234.

IPCC (2014). Climate Change 2014: Synthesis Report. Contribution of Working Groups I, II, and III to the Fifth Assessment Report of the Intergovernmental Panel on Climate Change. Core Writing Team, R. K. Pachauri and L. A. Meyer (Geneva: IPCC), 151.

IPCC (2019). IPCC Special Report on the Ocean and Cryosphere in a Changing Climate. eds H.-O. Poĺrtner, D. C. Roberts, V. Masson-Delmotte, P. Zhai, M. Tignor, E. Poloczanska, et al.

Kabat, P., Fresco, L., Stive, M., Veerman, C., van Alphen, J., Parmet, B., et al. (2009). Dutch coasts in transition, Vol. 2. New York: Macmillan Publishers Limited.

Karaliūnas, V., Jarmalavičius, D., Pupienis, D., Janušaitė, R., Žilinskas, G., and Karlonienë, D. (2020). Shore nourishment impact on coastal landscape transformation: An example of the lithuanian baltic sea coast. J. Coastal Res. 95:840. doi: 10.2112/SI95-163.1

King, D., Bird, D., Haynes, K., Boon, H., Cottrell, A., Millar, J., et al. (2014). Voluntary relocation as an adaptation strategy to extreme weather events. Int. J. Disaster Risk Reduct. 8, 83-90. doi: 10.1016/j.ijdrr.2014.02.006

Kirchhoff, C. J., Carmen Lemos, M., and Dessai, S. (2013). Actionable knowledge for environmental decision making: broadening the usability of climate science. Annu. Rev. Environ. Resour. 38, 393-414. doi: 10.1146/annurev-environ022112-112828

Kool, R., Lawrence, J., Drews, M., and Bell, R. (2020). Preparing for sealevel rise through adaptive managed retreat of a New Zealand stormwater and wastewater network. Infrastructures 5:92. doi: 10.3390/infrastructures511 0092

Kopp, R. E., Gilmore, E. A., Little, C. M., Lorenzo-Trueba, J., Ramenzoni, V. C., and Sweet, W. V. (2019). Usable science for managing the risks of sea-level rise. Earth's Future 7, 1235-1269. doi: 10.1029/2018EF001145 
Lauterjung, J., and Letz, H. (2017). 10 Years Indonesian Tsunami Early Warning System. Experiences, Lessons Learned and Outlook. Potsdam: GFZ German Research Centre for Geosciences, 69. doi: 10.2312/GFZ.7.1.2017.001

Lawrence, J., Bell, R., and Stroombergen, A. (2019). A hybrid process to address uncertainty and changing climate risk in coastal areas using dynamic adaptive pathways planning, multi-criteria decision analysis \& real options analysis: A new zealand application. Sustainability 11:406. doi: 10.3390/su110 20406

Lawrence, J., Boston, J., Bell, R., Olufson, S., Kool, R., Hardcastle, M., et al. (2020). Implementing Pre-emptive managed retreat: constraints and novel insights. Curr. Climate Change Rep. 6, 66-80. doi: 10.1007/s40641-02000161-z

Lawrence, J., and Haasnoot, M. (2017). What it took to catalyse uptake of dynamic adaptive pathways planning to address climate change uncertainty. Environ. Sci. Policy 68, 47-57. doi: 10.1016/j.envsci.2016.12.003

Lawrence, J., Stephens, S., Blackett, P., Bell, R. G., and Priestley, R. (2021). Climate services transformed: decision-making practice for the coast in a changing climate. Front. Mar. Sci. 8:703902. doi: 10.3389/fmars.2021.703902

Le Bars, D., Drijfhout, S., and Haasnoot, M. (2020). The future of sea level: More knowledge, more uncertainty. Vienna, Austria: EGU General Assembly, doi: 10.5194/egusphere-egu2020-7675

Le Cozannet, G., Thieblemont, R., Toimil, A., Meyssignac, B., Menendez, M., and Losada, I. J. (2019). Likely and high-end impacts of regional sea-level rise on european sandy coasts under business as usual greenhouse gas emissions. San Francisco, CA: AGU Fall Meeting.

Leonardi, N., Carnacina, I., Donatelli, C., Ganju, N. K., Plater, A. J., Schuerch, M., et al. (2018). Dynamic interactions between coastal storms and salt marshes: A review. Geomorphology 301, 92-107. doi: 10.1016/j.geomorph.2017.11.001

Linham, M. M., and Nicholls, R. J. (2010). Technologies for climate change adaptation: Coastal erosion and flooding. Roskilde, Denmark: UNEP Riso Centre on Energy, Climate and Sustainable Development.

Liu, G., Cai, F., Qi, H., Liu, J., Lei, G., Zhu, J., et al. (2020). A summary of beach nourishment in China: The past decade of practices. Shore Beach 2020, 65-73. doi: $10.34237 / 1008836$

Magnan, A., Christiansen, L., and Neufeldt, H. (2021). Framing the Adaptation Gap Report. Adaptation Gap Report 2020 United Nations Environment Programme.

Magnan, A. K., Schipper, E. L. F., and Duvat, V. K. E. (2020). Frontiers in climate change adaptation science: advancing guidelines to design adaptation pathways. Curr. Climate Change Rep. 6, 166-177. doi: 10.1007/s40641-020-00166-8

Martinez, G., Costas, S., and Ferreira, Ó (2020). The role of culture for coastal disaster risk reduction measures: Empirical evidence from northern and southern Europe. Adv. Climate Change Res. 11, 297-309. doi: 10.1016/j.accre. 2020.11.001

McGinlay, J., Jones, N., Clark, J., and Maguire-Rajpaul, V. A. (2021). Retreating coastline, retreating government? Managing sea level rise in an age of austerity. Ocean Coast. Manage. 204:105458. doi: 10.1016/j.ocecoaman.2020.105458

McIvor, A., Spencer, T., Möller, I., and Spalding, M. (2013). The response of mangrove soil surface elevation to sea level rise. Cambridge Coastal Research Unit Working Paper 42. Netherlands: The Nature Conservancy and Wetlands International.

Mcleod, E., Chmura, G. L., Bouillon, S., Salm, R., Björk, M., Duarte, C. M., et al. (2011). A blueprint for blue carbon: Toward an improved understanding of the role of vegetated coastal habitats in sequestering $\mathrm{CO}$ 2. Front. Ecol. Environ. 9, 552-560. doi: 10.1890/110004

Merkens, J.-L., Reimann, L., Hinkel, J., and Vafeidis, A. T. (2016). Gridded population projections for the coastal zone under the shared socioeconomic pathways. Glob. Planetary Change 145, 57-66. doi: 10.1016/j.gloplacha.2016.08. 009

Meur-Ferec, C., and Guillou, E. (2020). Interest of social representations theory to grasp coastal vulnerability and to enhance coastal risk management (Interés de la Teoría de las Representaciones Sociales para entender la vulnerabilidad costera y para mejorar la gestión de los riesgos costeros). PsyEcology 11, 78-89. doi: 10.1080/21711976.2019.1644003

Michelot, A. (2015). "Les risques naturels en zones côtière. De nouvelles perspectives à partir du droit de l'environnement," in Les risques naturels en zones côtières. Xynthia : enjeux politiques, questionnement juridiques, eds C. Laronde-Clérac, A. Mazeaud, and A. et Michelot (Rennes: Presses Universitaires de Rennes), 23-38.
Möller, I., Kudella, M., Rupprecht, F., Spencer, T., Paul, M., van Wesenbeeck, B. K., et al. (2014). Wave attenuation over coastal salt marshes under storm surge conditions. Nat. Geosci. 7, 727-731. doi: 10.1594/PANGAEA.836217

Morris, R. L., Bilkovic, D. M., Boswell, M. K., Bushek, D., Cebrian, J., Goff, J., et al. (2019). The application of oyster reefs in shoreline protection: Are we over-engineering for an ecosystem engineer? J. Appl. Ecol. 56, 1703-1711. doi: $10.1111 / 1365-2664.13390$

Nicholls, R. (2011). Planning for the impacts of sea level rise. Oceanography 24, 144-157. doi: 10.5670/oceanog.2011.34

Pagán, J. I., López, I., Aragonés, L., and Tenza-Abril, A. J. (2020). “Experiences with beach nourishments on the coast of Alicante, Spain," in Eighth International Symposium "Monitoring of Mediterranean Coastal Areas. Problems and Measurement Techniques", 1re éd Edn, Vol. 126, eds L. Bonora, D. Carboni, and M. De Vincenzi (Firenze, FI: Firenze University Press), 441-450.

Piggott-McKellar, A. E., McNamara, K. E., Nunn, P. D., and Watson, J. E. M. (2019). What are the barriers to successful community-based climate change adaptation? A review of grey literature. Local Environ. 24, 374-390. doi: 10. 1080/13549839.2019.1580688

Pinto, C. A., Silveira, T. M., and Teixeira, S. B. (2020). Beach nourishment practice in mainland Portugal (1950-2017): Overview and retrospective. Ocean Coast. Manage. 192:105211. doi: 10.1016/j.ocecoaman.2020.105211

Powell, E. J., Tyrrell, M. C., Milliken, A., Tirpak, J. M., and Staudinger, M. D. (2019). A review of coastal management approaches to support the integration of ecological and human community planning for climate change. J. Coast. Conserv. 23, 1-18. doi: 10.1007/s11852-018-0632-y

Ranasinghe, R. (2020). On the need for a new generation of coastal change models for the 21st century. Sci. Rep. 10:2010. doi: 10.1038/s41598-020-58376-x

Reed, M. S. (2008). Stakeholder participation for environmental management: A literature review. Biol. Conserv. 141, 2417-2431. doi: 10.1016/j.biocon.2008.07. 014

Rey-Valette, H., Rulleau, B., Hellequin, A.-P., Meur-Férec, C., and Flanquart, H. (2015). Second-home owners and sea-level rise: The case of the LanguedocRoussillon region (France). J. Policy Res. Tourism, Leisure Events 7, 32-47. doi: 10.1080/19407963.2014.942734

Rinde, E., Tjomsland, T., Hjermann, D. Ø, Kempa, M., Norling, P., and Kolluru, V. S. (2017). Increased spreading potential of the invasive Pacific oyster (Crassostrea gigas) at its northern distribution limit in Europe due to warmer climate. Mar. Freshw. Res. 68:252. doi: 10.1071/MF15071

Robert, S., and Schleyer-Lindenmann, A. (2021). How ready are we to cope with climate change? Extent of adaptation to sea level rise and coastal risks in local planning documents of southern France. Land Use Policy 104:105354. doi: 10.1016/j.landusepol.2021.105354

Rocle, N., Dachary-Bernard, J., and Rey-Valette, H. (2021). Moving towards multilevel governance of coastal managed retreat: Insights and prospects from France. Ocean Coast. Manage. 213:105892. doi: 10.1016/j.ocecoaman.2021. 105892

Rocle, N., Rey-Valette, H., Bertrand, F., Becu, N., Long, N., Bazart, C., et al. (2020). Paving the way to coastal adaptation pathways: An interdisciplinary approach based on territorial archetypes. Environ. Sci. Policy 110, 34-45. doi: 10.1016/j. envsci.2020.05.003

Rocle, N., and Salles, D. (2018). "Pioneers but not guinea pigs": Experimenting with climate change adaptation in French coastal areas. Policy Sci. 51, 231-247. doi: 10.1007/s11077-017-9279-z

Roelvink, F. E., Storlazzi, C. D., van Dongeren, A. R., and Pearson, S. G. (2021). Coral reef restorations can be optimized to reduce coastal flooding hazards. Front. Mar. Sci. 8:653945. doi: 10.3389/fmars.2021.653945

Salvador de Paiva, J. N., Walles, B., Ysebaert, T., and Bouma, T. J. (2018). Understanding the conditionality of ecosystem services: The effect of tidal flat morphology and oyster reef characteristics on sediment stabilization by oyster reefs. Ecol. Engin. 112, 89-95. doi: 10.1016/j.ecoleng.2017 .12 .020

Schneider, P., Lawrence, J., Glavovic, B., Ryan, E., and Blackett, P. (2020). A rising tide of adaptation action: Comparing two coastal regions of AotearoaNew Zealand. Climate Risk Manage. 30:100244. doi: 10.1016/j.crm.2020.100244 Scyphers, S. B., Beck, M. W., Furman, K. L., Haner, J., Keeler, A. G., Landry, C. E., et al. (2020). Designing effective incentives for living shorelines as a habitat conservation strategy along residential coasts. Conserv. Lett. 13:10. doi: $10.1111 /$ conl.12744 
See, J., and Wilmsen, B. (2020). Just adaptation? Generating new vulnerabilities and shaping adaptive capacities through the politics of climate-related resettlement in a Philippine coastal city. Glob. Environ. Change 65:102188. doi: 10.1016/j. gloenvcha.2020.102188

Shi, L. (2019). Promise and paradox of metropolitan regional climate adaptation. Environ. Sci. Policy 92, 262-274. doi: 10.1016/j.envsci.2018.11.002

Siders, A. R. (2019). Managed retreat in the United States. One Earth 1, 216-225. doi: 10.1016/j.oneear.2019.09.008

Sierra-Correa, P. C., and Cantera Kintz, J. R. (2015). Ecosystem-based adaptation for improving coastal planning for sea-level rise: A systematic review for mangrove coasts. Mar. Policy 51, 385-393. doi: 10.1016/j.marpol.2014. 09.013

Smith, G., Anderson, A., and Perkes, D. (2021). New urbanism and the hazard transect overlay district: Improving the integration of disaster resilience and design in coastal areas. Landscape J. 40, 35-47. doi: 10.3368/wplj.40.1.35

Somphong, C., Udo, K., Ritphring, S., and Shirakawa, H. (2020). Beach nourishment as an adaptation to future sandy beach loss owing to sea-level rise in Thailand. J. Mar. Sci. Engin. 8:659. doi: 10.3390/jmse8090659

Stive, M. J. F., de Schipper, M. A., Luijendijk, A. P., Aarninkhof, S. G. J., van GelderMaas, C., van Thiel de Vries, J. S. M., et al. (2013). A new alternative to saving our beaches from sea-level rise: The sand engine. J. Coast. Res. 290, 1001-1008. doi: 10.2112/JCOASTRES-D-13-00070.1

Sutton-Grier, A. E., Wowk, K., and Bamford, H. (2015). Future of our coasts: The potential for natural and hybrid infrastructure to enhance the resilience of our coastal communities, economies and ecosystems. Environ. Sci. Policy 51, 137-148. doi: 10.1016/j.envsci.2015.04.006

Temmerman, S., Meire, P., Bouma, T. J., Herman, P. M. J., Ysebaert, T., and De Vriend, H. J. (2013). Ecosystem-based coastal defence in the face of global change. Nature 504, 79-83. doi: 10.1038/nature12859

Thi Thu Trang, N. (2016). Architectural Approaches to a Sustainable Community with Floating Housing Units Adapted to Climate Change and Sea Level Rise in Vietnam. Int. J. Archit. Environ. Engin. 10, 168-179.

Toimil, A., Camus, P., Losada, I. J., and Alvarez-Cuesta, M. (2021). Visualising the uncertainty cascade in multi-ensemble probabilistic coastal erosion projections. Front. Mar. Sci. 8:683535. doi: 10.3389/fmars.2021.683535

Treuer, G., Broad, K., and Meyer, R. (2018). Using simulations to forecast homeowner response to sea level rise in South Florida: Will they stay or will they go? Glob. Environ. Change 48, 108-118. doi: 10.1016/j.gloenvcha.2017.10.008

van de Vuurst, P., and Escobar, L. E. (2020). Perspective: climate change and the relocation of Indonesia's Capital to Borneo. Front. Earth Sci. 8:5. doi: 10.3389/ feart.2020.00005

van Rijn, L. C. (2011). Coastal erosion and control. Ocean Coast. Manage. 54, 867-887. doi: 10.1016/j.ocecoaman.2011.05.004 van Slobbe, E., de Vriend, H. J., Aarninkhof, S., Lulofs, K., de Vries, M., and Dircke, P. (2013). Building with Nature: In search of resilient storm surge protection strategies. Nat. Hazards 66, 1461-1480. doi: 10.1007/s11069-013 $-0612-3$

Warner, J. F., van Staveren, M. F., and van Tatenhove, J. (2018). Cutting dikes, cutting ties? Reintroducing flood dynamics in coastal polders in Bangladesh and the netherlands. Int. J. Disaser. Risk Reduct. 32, 106-112. doi: 10.1016/j. ijdrr.2018.03.020

Werners, S. E., Wise, R. M., Butler, J. R. A., Totin, E., and Vincent, K. (2021). Adaptation pathways: A review of approaches and a learning framework. Environ. Sci. Policy 116, 266-275. doi: 10.1016/j.envsci.2020.11.003

Woodworth, P. L., Melet, A., Marcos, M., Ray, R. D., Wöppelmann, G., Sasaki, Y. N., et al. (2019). Forcing factors affecting sea level changes at the coast. Surveys Geophys. 40, 1351-1397. doi: 10.1007/s10712-019-09531-1

World Bank (2018). Senegal - Saint-Louis Emergency Recovery and Resilience Project (P166538) Combined Project Information Documents / Integrated Safeguards Datasheet (PID/ISDS)'. Report No: PIDISDSA24100. Available Online at: https://documents1.worldbank.org/curated/en/ 501701524080197497/pdf/Project-Information-Document-IntegratedSafeguards-Data-Sheet-Senegal-Saint-Louis-Emergency-Recovery-andResilience-Project-P166538.pdf.

Zhang, C., Tian, H., Chen, G., Chappelka, A., Xu, X., Ren, W., et al. (2012). Impacts of urbanization on carbon balance in terrestrial ecosystems of the Southern United States. Environ. Pollut. 164, 89-101. doi: 10.1016/j.envpol.2012.01.020

Conflict of Interest: The authors declare that the research was conducted in the absence of any commercial or financial relationships that could be construed as a potential conflict of interest.

Publisher's Note: All claims expressed in this article are solely those of the authors and do not necessarily represent those of their affiliated organizations, or those of the publisher, the editors and the reviewers. Any product that may be evaluated in this article, or claim that may be made by its manufacturer, is not guaranteed or endorsed by the publisher.

Copyright (ㄷ 2021 Bongarts Lebbe, Rey-Valette, Chaumillon, Camus, Almar, Cazenave, Claudet, Rocle, Meur-Férec, Viard, Mercier, Dupuy, Ménard, Rossel, Mullineaux, Sicre, Zivian, Gaill and Euzen. This is an open-access article distributed under the terms of the Creative Commons Attribution License (CC BY). The use, distribution or reproduction in other forums is permitted, provided the original author(s) and the copyright owner(s) are credited and that the original publication in this journal is cited, in accordance with accepted academic practice. No use, distribution or reproduction is permitted which does not comply with these terms. 